\title{
Evaluation of soil and water conservation practices in the north-western Ethiopian highlands using multi-criteria analysis
}

\author{
Akalu Teshome ${ }^{1,2 *}$, Jan de Graaff ${ }^{1}$ and Leo Stroosnijder ${ }^{1}$ \\ 1 Soil Physics and Land Management Group, Environmental Science Department, University of Wageningen, Wageningen, Netherlands \\ ${ }^{2}$ Amhara Regional Agricultural Research Institute, Bahir Dar, Ethiopia
}

Edited by:

Luuk Fleskens, University of Leeds, UK

Reviewed by:

Robert Zougmoré, International Crops Research Institute for the Semi-Arid Tropics, Mali

Doan Nainggolan, University of Aarhus, Denmark

*Correspondence:

Akalu Teshome, Amhara Regional Agricultural Research Institute, P.O.

Box +527, Bahir Dar, Ethiopia

e-mail: akalu_firew@yahoo.com
Investments by farmers in soil and water conservation (SWC) practices are influenced by the physical effectiveness, financial efficiency, and social acceptability of these practices. The objective of this study is to evaluate different SWC practices in the north-western highlands of Ethiopia using various qualitative criteria and weightings based on ecological, economic and social impacts using Multi-Criteria Analysis (MCA). The study reveals that MCA is a useful evaluation tool that takes into account non-monetary and less quantifiable effects of SWC practices. Farmers employ a range of criteria to evaluate the performance of SWC practices. The relative importance of each criterion in their selection of SWC alternatives depends mostly on slope categories. In steeply sloping areas, farmers assigned the highest score for criteria related to ecological impacts; whilst preferring practices with stronger positive economic impacts in moderate and gentle sloping areas. Policy makers and development practitioners are encouraged to pay greater attention to both farmer preferences and slope specific circumstances when designing SWC strategies and programmes.

Keywords: multi-criteria analysis, soil and water conservation, farmer preferences, slope, Ethiopia

\section{INTRODUCTION}

Agriculture is the major source of livelihood in Ethiopia. However, land degradation in the form of soil erosion has hampered agricultural productivity and economic growth of the nation (Haileslassie et al., 2005; Hengsdijk et al., 2005; Balana et al., 2010). Land degradation, low agricultural productivity and poverty are critical and closely related problems in the Ethiopian highlands (Pender and Gebremedhin, 2007; Yitbarek et al., 2012).

Investments ${ }^{1}$ in soil and water conservation (SWC) practices enhance crop production, food security and household income (Adgo et al., 2013). Recognizing these connections, the government of Ethiopia is promoting SWC technologies for improving agricultural productivity, household food security and rural livelihoods. Particularly in the Ethiopian highlands, different SWC technologies have been promoted among farmers to control erosion. These technologies include stone bunds, soil bunds and Fanya juu bunds (made by digging a trench and moving the soil uphill to form an embankment). However, the adoption rates of these SWC technologies vary considerably within the country (Kassie et al., 2009; Tefera and Sterk, 2010; Tesfaye et al., 2013; Teshome et al., 2014), largely because investments by farmers in SWC are influenced by the ecological, economic and social impacts of the SWC technologies.

\footnotetext{
${ }^{1}$ Investments refer to any efforts (e.g. labor, knowledge, and time) made by farmers to combat water erosion and enhance soil fertility.
}

The impact of SWC measures in Ethiopia and elsewhere is mostly evaluated in monetary terms (cost-benefit analysis; CBA) (Bizoza and de Graaff, 2012; Teshome et al., 2013). However, SWC measures also have ecological and social impacts that cannot be easily quantified in monetary values (Tenge, 2005). Moreover, CBA is sometimes criticized in that it does not take into account the interactions between different impacts. More rigorous evaluation methods of SWC measures are of paramount importance in quantifying the monetary and non-monetary value of SWC measures to ensure better decision-making processes of policy makers and development practitioners.

Availability of several SWC alternatives, conflicting objectives and a range of evaluation criteria of farmers hamper their decision-making and adoption of SWC measures (Amsalu, 2006). Farmers' investment objectives often differ considerably from those of researchers and extension personnel, as they have other objectives in addition to reducing soil loss and maximizing financial benefits of SWC measures (Tenge, 2005). These objectives are often conflicting, resulting in no single SWC measure that can provide the best outcome for all farmers.

Therefore, there is a need to evaluate the objectives and criteria of farm households in decision-making of SWC practices based on ecological, economic and social impacts. In order to identify and analyse multiple and conflicting objectives and goals, MultiCriteria Analysis (MCA) represents a more suitable tool (Romero and Rehman, 2003). In addition, MCA methods are an appropriate modeling tool for addressing economic-environmental 
evaluation issues (Munda et al., 1994; Mendoza and Martins, 2006).

The objective of this study is to evaluate different SWC practices using qualitative criteria by different stakeholders (farmers and experts) based on perceived ecological, economic and social impacts.

\section{MULTIPLE CRITERIA ANALYSIS (MCA) FOR SOIL AND WATER CONSERVATION EVALUATION}

Most SWC investment activities are evaluated using a CBA, which assumes that complex soil and water objectives can be converted into one basic objective of "maximizing profit." However, the objective function consists of a single choice criterion, yet within SWC investments, there are usually several objectives or goals (Prato, 1999). Therefore, a discrete MCA has been developed as a decision-making tool when different objectives have to be fulfilled. Recently, Fleskens et al. (2014) revealed that scenario assessments with integrated models help determine locationspecific, financially viable technologies to effectively combat land degradation problems, and provide input into multilevel land management decision-making processes. Moreover, choice experiments, a stated preference valuation method, are also a tool that can assign monetary values to environmental impact assessment (Vega and Alpízar, 2011).

MCA is a decision-making tool applied to choice problems in the face of a number of different alternatives and conflicting criteria (Hajkowicz et al., 2000). CIFOR (1999) defined MCA as a decision-making tool developed for complex multi-criteria problems that include qualitative and/or quantitative aspects of the problem in the decision-making process. MCA is an evaluation method, based on sustainable development economic theory, that ranks or scores the performance of decision options against multiple criteria (Hajkowicz, 2007), ensuring the final results have clear meaning in terms of sustainability (Boggia and Cortina, 2010).

The main characteristics of MCA are: multiplicity of objectives, heterogeneity of objectives and plurality of decision makers (Seo and Sakawa, 1988). However, in terms of evaluating SWC practices, MCA has some advantages and disadvantages (de Graaff, 1996; Prato, 1999) (Table 1), but offers great potential in addressing the shortcomings of other SWC evaluation methods.

For evaluation of SWC investments, CBA only compares one "with" case with one "without case" (or "before" and "after" case), resulting in all effects being valued in monetary values, and focused mostly on the efficiency criterion. MCA has the disadvantage that it does not allow for an easy comparison of streams of costs and benefits over time, and relies on subjective weightings attached to several criteria by the stakeholders concerned and represented (Table 1). An appropriate solution to evaluate SWC is the use of CBA results as one of the criteria (efficiency) in the MCA evaluation of SWC measures (de Graaff, 1996). Therefore, MCA appears to be one of the more appropriate tools to evaluate SWC practices.

\section{STEPS IN MULTI-CRITERIA ANALYSIS (MCA) METHODS}

MCA uses a number of defining steps to identify the best alternatives on the basis of relevant criteria (Voogd, 1982; Munda et al.,

1994; Tenge, 2005; Hajkowicz and Higgins, 2008; Ananda and Herath, 2009). The major steps in the MCA are the following:

Step 1: Determination of objectives.

Step 2: Identification of alternatives/options, that contributes to achieving the objectives.

Step 3: Determination of the evaluation criteria to assess the performance of the alternatives.

Step 4: Determination of the effects (score) on alternatives. The effects of alternatives are identified, measured (quantitative or qualitative) and determined according to the measurable criteria set, established in step 3.

Step 5: Standardization of the effects.

Making the unit of scores comparable, on a scale between 0 and 1 , eliminates the effect of different dimension scoring of alternatives.

Step 6: Formulation of weights.

Weights are assigned to criteria by farmers, policymakers, or other stakeholders to represent their relative importance for the respective group.

Step 7: Aggregation and ranking.

Involves combining weighted scores for each alternative. Among the discrete MCA methods, the most important aggregation methods are the Additive Weighting and the Sequential Elimination methods.

\section{MATERIALS AND METHODS \\ STUDY AREAS}

The study was undertaken in three watersheds in the East and West Gojam Zones of the Amhara region of Ethiopia, i.e., the Anjeni, Dijil, and Debre-Mewi watersheds (Figure 1). The watersheds are part of the north-western highlands of Ethiopia. These watersheds were selected because of their specific experience with SWC activities. Moreover, the watersheds have diverse

Table 1 | Advantages and disadvantages of MCA for evaluating SWC.

Advantages of MCA Disadvantages of MCA

Focus on several objectives and alternatives

Considered the intangible effects of SWC.

Use of both qualitative and quantitative effects.

Holistic approach: it can also incorporate CBA and other

financial efficiency criteria.

Increases the rationality of the decision process.

Identifies gaps in knowledge in SWC practices.

Interactive method
Non-comparability among objectives.

Exposed to subjectivity problem: subjective weights attached to several criteria.

Use of qualitative scales, where quantitative could be used. Different methods give different results.

Difficult to incorporate the time dimension.

Pays little attention to uncertainty and to possible trade-offs among some of the objectives.

Different conflicting evaluation criteria are taken into consideration. 


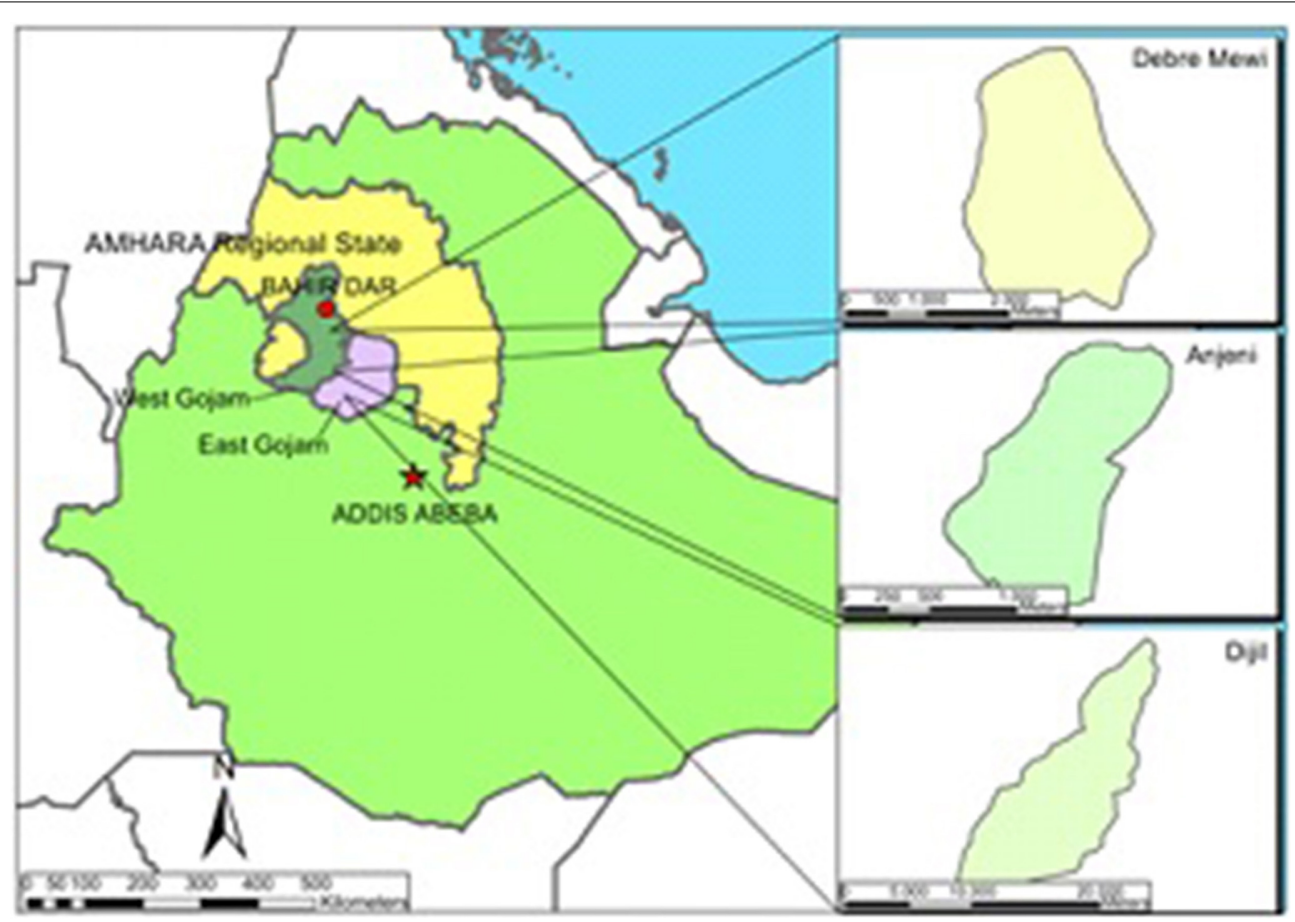

FIGURE 1 | Map of study areas in Amhara regional state, Ethiopia.

biophysical and socio-economic characteristics (Table 2). The dominant farming system in the watersheds is characterized as crop-livestock mixed farming.

\section{DATA COLLECTION}

Farmers and experts are the main stakeholders in SWC activities in the Ethiopian highlands. Qualitative and quantitative data were collected from these stakeholders using group discussions and a formal survey in 2013. Two group discussions were undertaken in each watershed. The number of participants in each group ranged from 9-11 farmers. Group discussions were followed by an individual survey to crosscheck the information provided. For this survey a total of 50 farm households (20 from Debre Mewi, 15 from Anjeni and 15 from Dijil) were carefully selected from an earlier much larger household survey ${ }^{2}$. In addition, 16 experts were interviewed from different levels of the Department of Agriculture (kebele ${ }^{3}$, district, zone, and region).

SWC alternatives and evaluation criteria were identified during the two previous surveys and group discussions (Teshome et al., 2014, Forthcoming). SWC alternatives and evaluation criteria were compiled and presented for discussions with farmers. During the group discussions, some SWC alternatives and criteria were removed as they were either not very relevant, or not commonly practiced in the prevalent farming system

\footnotetext{
${ }^{2}$ These 50 farm households are part of large survey of households. This large survey included 60, 125, and 115 households from Anjeni, Dijil, and Debre Mewi watersheds, respectively.

${ }^{3}$ Kebele is the lowest administrative body in Ethiopia and is part of the subdistrict.
}

(alternatives and criteria were fine-tuned during group discussions). For example, for farmers in Anjeni, soil bunds were not important in their watershed. Thus, weightings were reassigned through group consensus to criteria dependent on the different slope categories (steep, moderate, and gentle). This is because farmers mainly classify their land parcels into three categories, i.e., steep (tedafat), moderate (mekakelegna), and gentle (deledala/medama). A fixed point scoring technique was applied in this study (Hajkowicz et al., 2000), where the decision-maker is required to distribute a fixed number of points among the criteria. Thus, a higher point score indicates that the criterion has greater importance. Fixed point scoring is the most direct means of obtaining weighting information from the decision maker.

\section{SOIL AND WATER CONSERVATION ALTERNATIVES}

SWC measures are part and parcel of the farming system evident in the study areas. Almost all farmers perceived erosion problems while many of them also believed that SWC measures are profitable (Teshome et al., 2013). Thus, different SWC measures to avert erosion problems were introduced by government and non-government organizations. Soil bunds, Fanya juu bunds and stone bunds are the major SWC measures that are widely implemented by farmers. Therefore, these three SWC measures and the "No measure" alternative were included in the evaluation.

\section{Soil bunds}

Soil bunds are embankments made from topsoil along the contour to control erosion (Figure 2). They require less labor for 
construction compared to stone and Fanya juu bunds as excavated material from the ditch is placed downhill rather than uphill, as is the case in the construction of Fanya juu bunds. However, soil bunds require more labor for maintenance than Fanya juu and stone bunds. The uphill drains of the soil bund are impacted by accumulated material (silt) and therefore require more labor to regularly excavate the ditches, as farmers need to ensure effective evacuation of excess water. Grass is grown on the riser to stabilize the bunds. Soil bunds can be easily eroded during heavy rainfall in steeply sloping areas.

\section{Fanya juu bunds}

Fanya juu bunds are made by digging a trench and moving the soil uphill to form an embankment (Figure 2), and are thus more labor-intensive during construction. A terrace can therefore be created in a relatively short period of time. They provide an opportunity to grow fodder or grass on the riser, but they can also experience water-logging.

Table 2 | Socio- and physical characteristics of the study watersheds.

\begin{tabular}{llll}
\hline Features & Anjeni & Dijil & Debre Mewi \\
\hline Size of watershed (ha) & 113 & 936 & 523 \\
Altitude (m.a.s.l) & 2450 & 2480 & 2300 \\
Average annual rainfall (mm) & 1790 & 1300 & 1260 \\
Dominant soil types & Alisols, & Nitosols & Vertic Nitosols, \\
& Nitosols, & & Nitosols, \\
& Regosols, & & Vertisols \\
& Leptisols & & \\
Degradation & Degraded & Very & Not heavily \\
& & degraded & degraded \\
Soil pH & 5.7 & 4.3 & 6.7 \\
Slope class & & & \\
$\quad$ Flat to gentle (<10\%) (\%) & 30.5 & 13.9 & 19.7 \\
$\quad$ Medium (10-20\%) (\%) & 28.6 & 41.4 & 41.9 \\
$\quad$ Steep (>20\%) (\%) & 40.9 & 44.7 & 38.4 \\
Dominant crop in farming & Barley & Oats & Tef \\
systems & & & \\
Productivity & Low & Low & High \\
Number of households & 95 & 628 & 324 \\
All weather road & Poor & Good & Good \\
Distance to district town (km) & 20 & 8 & 12 \\
\hline
\end{tabular}

Sources: SCRP, 1991; Liu et al., 2008; Zegeye, 2009; Tesfaye, 2011.

\section{Stone bunds}

Stone bunds are usually constructed where stones are readily available on or near the field. Stone bunds are stable and durable measures. They can reduce runoff and soil erosion in steeply sloping areas, and excess water can pass more easily through stone terraces. However, construction does require a large amount of labor. Furthermore, they are not convenient for ox-plowing and can harbor rodents.

\section{No measures}

The No measure is one of the options available in the farmers' SWC investment decision-making. This alternative would be preferred by farmers when SWC measures have minimal impacts (ecologically, economically, and socially).

\section{DATA ANALYSIS}

Data analysis included the ranking of the most important SWC alternatives and standardization of the effects. Average weightings were used in our analysis to accommodate the different views of the farmers and experts on the relative importance of each criterion. Farmers and experts evaluated SWC measures by giving scores to each criteria on a scale of 1 for worst and 4 for best (and 3 in case of Anjeni, where only three alternatives were considered). We used the mode (most typical value) to aggregate rankings of individual farmers and experts. Scoring of the alternatives was also calculated by averaging the scales to crosscheck the results.

Regime Analysis method was used to obtain a complete ranking and further detailed information on the relative importance between the alternatives (Hinloopen and Nijkamp, 1990). The Regime Analysis method is one of the most common weighting methods, particularly in the case of qualitative data. This method is used to analyse ordinal and cardinal data. This method is based on pairwise comparison of two alternatives i according to criteria j (Hinloopen and Nijkamp, 1990).

Consider two alternatives $i$ and $i^{\prime}$. The pairwise comparison of these two alternatives according to criterion $j\left(e_{i i}, j\right)$ is therefore:

$$
\begin{array}{r}
e_{i i^{\prime} j}=1 \text { if } p_{i j}>p_{i^{\prime} j} \\
e_{i i^{\prime} j}=-1 \text { if } p_{i j}<p_{i^{\prime} j}
\end{array}
$$

Where $\mathrm{p}_{\mathrm{ij}}$ and $\mathrm{p}_{\mathrm{i}^{\prime} \mathrm{j}}$ are the ranks of alternatives $\mathrm{i}$ and $\mathrm{i}^{\prime}$ according to criteria $\mathrm{j}$. The regime vector $\left(\mathrm{e}_{\mathrm{ii}^{\prime}}\right)$ for each pair of alternatives is then constructed by extending the comparison of the alternatives
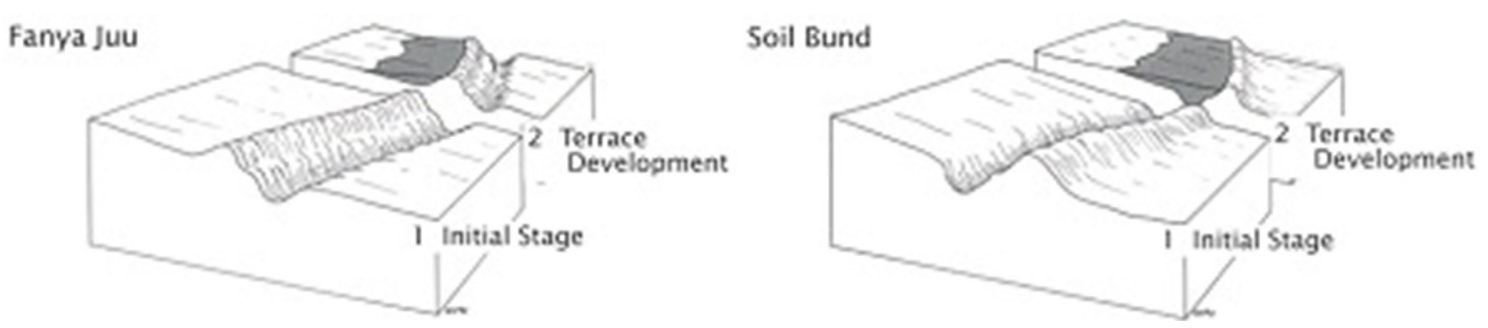

FIGURE 2 | Different types of SWC measures. Left: Fanya juu. Right: Soil bund. Source: (Haile et al., 2006). 
$\mathrm{i}$ and $\mathrm{i}^{\prime}$ to all criteria $\mathrm{j}=1,2, \ldots \mathrm{J}$ as follows:

$$
\mathrm{e}_{\mathrm{ii}^{\prime}}=\left(\mathrm{e}_{\mathrm{ii}}, 1, \mathrm{e}_{\mathrm{ii}}, 2, \ldots \mathrm{e}_{\mathrm{ii}}, \mathrm{J}\right)
$$

Positive "+" and negative "-" signs are used to indicate the relative dominance of one alternative over another, and " 0 " for no dominance. Based on the pairwise comparison of the alternatives obtained, the weighted dominance of alternative $i$ with respect to $\mathrm{i}^{\prime}\left(\mathrm{p}_{\mathrm{ii}^{\prime}}\right)$ is defined as:

$$
p_{i i^{\prime}}=\sum_{j=1}^{j} w_{j} * e_{i i^{\prime}, j}
$$

where

$\mathrm{w}_{\mathrm{j}}=$ weight relative to criterion $\mathrm{j}$,

$\mathrm{e}_{\mathrm{ii}^{\prime}}=$ pairwise comparison of alternative $\mathrm{i}$ and $\mathrm{i}^{\prime}$, and

$\mathrm{j}=$ the criterion.

\section{RESULTS}

\section{MAJOR ACTORS AND THEIR OBJECTIVES}

Erosion has adverse impacts on ecological, economic, and social aspects of farming communities. Farmers evaluate these multiple effects of the problem in their SWC investment decisions. In our formal and informal surveys we found that the major objectives of farmers in relation to SWC investments are ecological restoration (erosion control, enhanced soil fertility and increased water retention), economic benefits (increase production and decrease costs), and diminishing socially adverse effects of erosion and SWC measures. Similarly, the major objective revealed from the experts is to improve the livelihood of the farmers through comprehensive and integrated natural resource management and development.

\section{EVALUATION CRITERIA AND WEIGHTINGS}

Farmers and experts defined and used 10 evaluation criteria to evaluate SWC measures, which were then categorized into ecological, economic, social, and other criteria (Table 3 ).

\section{Ecological criteria}

Three criteria were identified for evaluating the ecological impacts of SWC alternatives. The criteria reveal that farmers would like SWC measures that are effective in erosion control, enhance soil fertility and improve water retention.

\section{Economic criteria}

Four criteria were mentioned to evaluate the economic impact of SWC alternatives. These evaluation criteria focus on the costs and benefits aspects of SWC alternatives.

\section{Social and other criteria}

Farmers in the study areas predominantly preferred SWC measures that have social benefits as well as measures that have no adverse effects on the farming system.

Farmers and experts gave weightings for the different evaluation criteria (Tables 4, 5). The results show that farmers and experts gave different weights and that these vary by slope category. The ecological impact criteria had the highest weighting within the steep slope category. On the other hand, economic impact criteria received the highest weighting in the gentle slope category. According to the farmers' views steeper slopes are more prone to erosion and that it is relatively more important to preserve them. The gentle plots, on the other hand, have higher economic potential.

Farmers gave relatively high scores to the social and other impacts criteria of SWC measures compared to the experts (Tables 4, 5). These criteria are: contributions of SWC measures to avoid disputes with adjacent farmers due to erosion, ox-plowing convenience of the measures and the risk of pest harboring effects of the measures. This shows that farmers pay more attention to everyday aspects of their lives during SWC investments while experts have larger scales than the field/farm, e.g., watershed level, in mind.

Anjeni farmers gave a higher weighting for maximizing crop yield, maximizing plowing convenience, and minimizing disputes with adjacent farmers as compared to other watersheds. This could be due to long term SWC activities implemented in the watershed within the last three decades and thereby farmers perceived the benefits of conservation measures over time. Most of the Fanya juu bunds in Anjeni have stabilized into bench terraces.

\begin{tabular}{|c|c|c|}
\hline Objectives & Criteria & $\begin{array}{l}\text { Unit of } \\
\text { measurement }\end{array}$ \\
\hline \multicolumn{3}{|l|}{ ECOLOGICAL IMPACTS } \\
\hline Erosion control (C1) & $\begin{array}{l}\text { Minimize soil } \\
\text { loss }\end{array}$ & Rank \\
\hline Enhance soil fertility (C2) & $\begin{array}{l}\text { Minimize } \\
\text { nutrient loss }\end{array}$ & Rank \\
\hline Water retention (C) & $\begin{array}{l}\text { Maximize water } \\
\text { retention }\end{array}$ & Rank \\
\hline \multicolumn{3}{|l|}{ ECONOMIC IMPACTS } \\
\hline Crop yields (C4) & $\begin{array}{l}\text { Maximize crop } \\
\text { yields }\end{array}$ & Rank \\
\hline Grass production (C5) & $\begin{array}{l}\text { Maximize grass } \\
\text { production }\end{array}$ & Rank \\
\hline $\begin{array}{l}\text { Labor requirements for } \\
\text { establishment (C6) }\end{array}$ & $\begin{array}{l}\text { Minimize labor } \\
\text { for } \\
\text { establishment }\end{array}$ & Rank \\
\hline Maintenance costs (C7) & $\begin{array}{l}\text { Minimize } \\
\text { maintenance } \\
\text { costs }\end{array}$ & Rank \\
\hline \multicolumn{3}{|l|}{ SOCIAL AND OTHER IMPACTS } \\
\hline Ox-plowing convenience (C8) & $\begin{array}{l}\text { Maximize } \\
\text { ox-plowing } \\
\text { convenience }\end{array}$ & Rank \\
\hline $\begin{array}{l}\text { Risk of pest harboring effect } \\
\text { (C9) }\end{array}$ & $\begin{array}{l}\text { Minimize risk of } \\
\text { pest harboring } \\
\text { effect }\end{array}$ & Rank \\
\hline $\begin{array}{l}\text { Avoid dispute with adjacent } \\
\text { farmers (C10) }\end{array}$ & $\begin{array}{l}\text { Minimize } \\
\text { dispute with } \\
\text { adjacent farmers }\end{array}$ & Rank \\
\hline
\end{tabular}

Table 3 | Farmers'/experts' evaluation criteria of SWC measures.

Source: Own surveys. 
This results in the diminution of slope angles and increased topsoil depth behind the bunds, which has a positive effect on yields.

\section{FARMERS AND EXPERTS MULTI-CRITERIA RANKING OF THE ALTERNATIVES}

The results of farmers' and experts' ranking of SWC measures based on the evaluation criteria are presented in Tables 6-8. The scores indicate the perceived level of importance of each SWC alternative with respect to the criteria defined.

Farmers and experts ranked stone bunds first for erosion control in the steep slope category in the three watersheds, while soil bunds are preferred by experts and farmers in Debre Mewi and Dijil watershed to control erosion in the moderate slope category. Soil bunds are not common practice in Anjeni watershed, but regardless, farmers selected Fanya juu bunds to control erosion in the moderate slope category. In all watersheds, farmers gave priority to Fanya juu bunds to control erosion in gentle slope areas. Farmers' rankings of SWC alternatives for maximizing crop yield were highly correlated with the degree of erosion control of the measures, except for Fanya juu in Debre Mewi. Even though Fanya juu bunds were preferred to control erosion on gentle slopes, their contribution to increased yield was not ranked as high, probably due to the water logging effects of the measures in Debre Mewi (Tables 6-8).

Farmers did not prefer stone bunds due largely to high labor demands for establishment, plowing inconvenience and the risks of pest harboring effects, as evident across all watersheds and slope categories (Tables 6, 7). Soil bunds were next to "no measure" ranked first in minimizing labor requirements for establishment of SWC. On the other hand, it was ranked last in minimizing maintenance costs. In general, farmer preferences reflect their experiences, perceptions, and attitudes about the merits and drawbacks of SWC alternatives under different situations.

\section{THE EVALUATION MATRIX}

Pairwise comparisons refine a complex decision problem into a series of one-to-one judgments regarding the significance of each alternative relative to the criterion that it describes (Balana et al., 2010). A pairwise comparison of the SWC alternatives against the evaluation criteria is presented in Table 9. Each alternative under a given criterion is compared with every other alternative under that criterion to evaluate its relative importance.

\section{RANKING OF THE ALTERNATIVES}

The weighted scores ( $\mathrm{p}$ ) of the pairwise comparisons and overall rank of the alternatives for each slope category are given in Tables 10, 11. The higher the evaluation score, the better the perceived performance of the SWC alternative. The evaluation score of each alternative pair in descending order provides a list of SWC measure from best to worst performing.

\section{Steep slope category}

In steeply sloping areas, stone bunds are the most viable SWC alternative in all watershed areas, followed by soil bunds. Stone bunds are durable and stable in controlling high runoff in steep areas. Stone bunds are also the first alternative for experts. Other SWC measures are easily eroded by runoff. Farmers

Table 5 | Experts' weighting (\%) sets of evaluation criteria for each slope category.

\begin{tabular}{lccc}
\hline Criteria & \multicolumn{3}{c}{ Slope } \\
\cline { 2 - 4 } & Steep & Moderate & Gentle \\
\hline Erosion control & 30.4 & 21.4 & 10 \\
Enhance fertility & 15.7 & 14.1 & 9.9 \\
Water retention & 13.1 & 11.4 & 14.7 \\
Crop yields & 12.6 & 21.2 & 30.2 \\
Grass production & 9.5 & 8.1 & 5.5 \\
Labor for establishment & 3.5 & 7.1 & 10.9 \\
Maintenance cost & 3.9 & 6.1 & 7.5 \\
Plowing convenience & 2.1 & 4.2 & 5.9 \\
Pest harboring effect & 2.8 & 3.5 & 4.3 \\
Dispute with adjacent farmers & 5.9 & 2.9 & 1.1 \\
\hline Total (\%) & 100 & 100 & 100
\end{tabular}

Table 4 | Farmers' weight sets of evaluation criteria for each slope category in percentages.

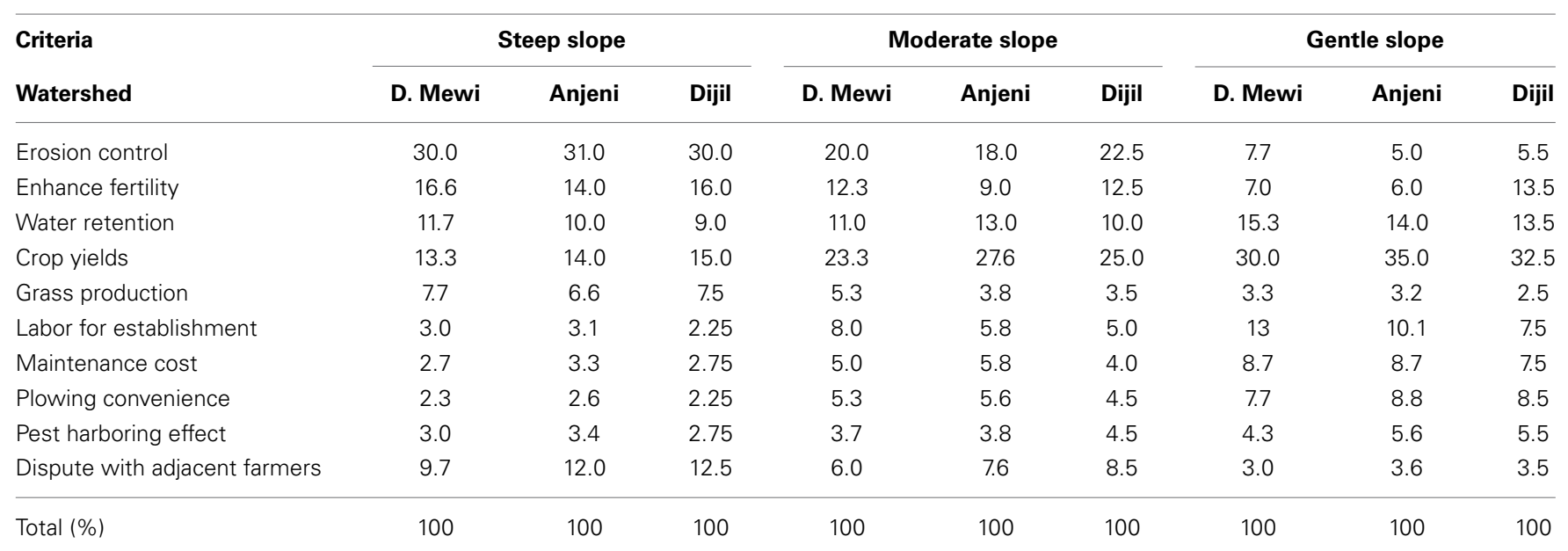


Table 6 | Farmers' ranking of SWC measures on the evaluation criteria for different slopes (4, Best; 1, Worst): Debre Mewi and Dijil watersheds.

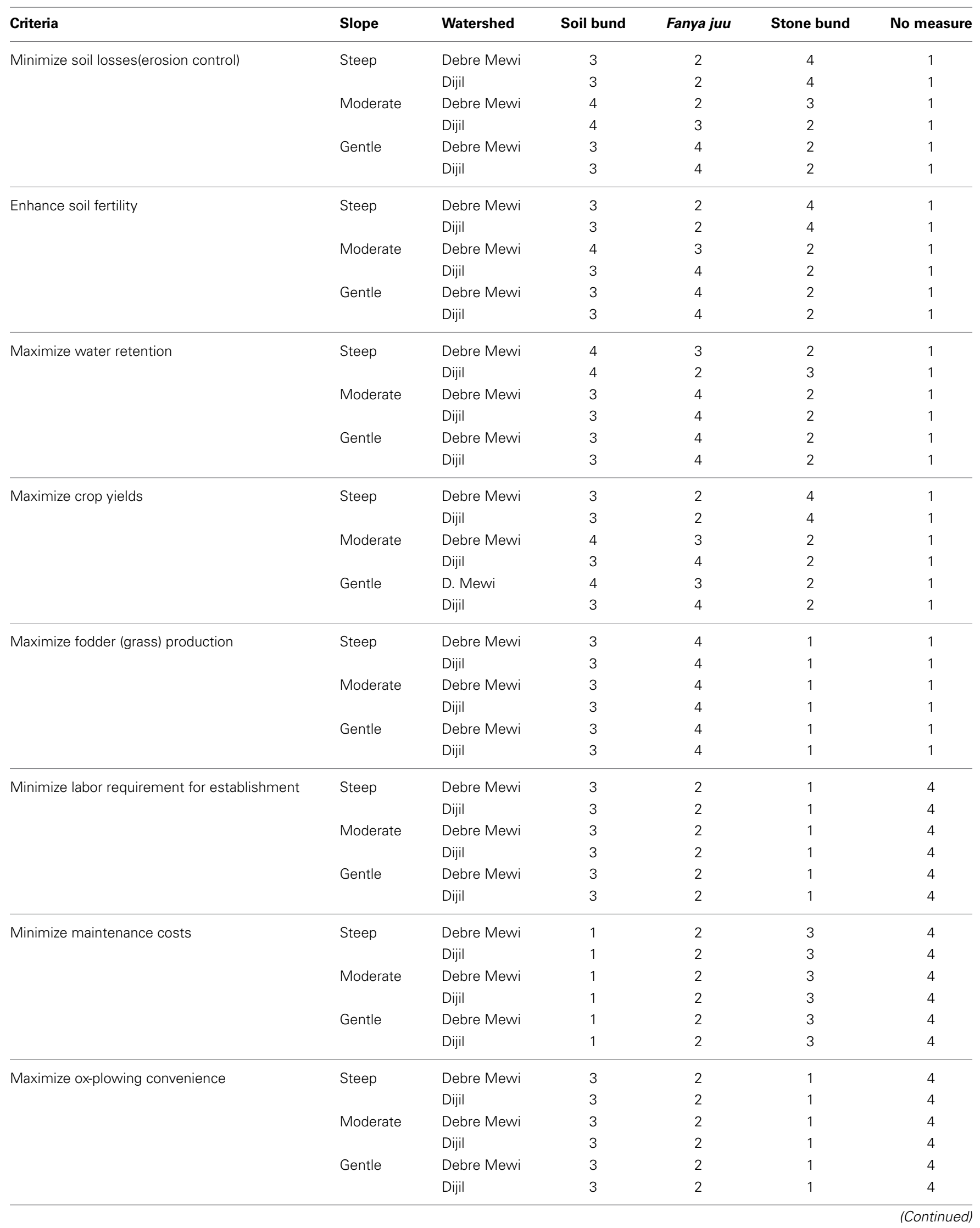


Table 6 | Continued

\begin{tabular}{|c|c|c|c|c|c|c|}
\hline Criteria & Slope & Watershed & Soil bund & Fanya juu & Stone bund & No measure \\
\hline \multirow[t]{6}{*}{ Minimize risks of pest harboring effect } & Steep & Debre Mewi & 2 & 3 & 1 & 4 \\
\hline & & Dijil & 3 & 2 & 1 & 4 \\
\hline & Moderate & Debre Mewi & 2 & 3 & 1 & 4 \\
\hline & & Dijil & 3 & 2 & 1 & 4 \\
\hline & Gentle & Debre Mewi & 2 & 3 & 1 & 4 \\
\hline & & Dijil & 3 & 2 & 1 & 4 \\
\hline \multirow[t]{6}{*}{ Minimize dispute with adjacent farmers } & Steep & Debre Mewi & 3 & 2 & 4 & 1 \\
\hline & & Dijil & 3 & 2 & 4 & 1 \\
\hline & Moderate & Debre Mewi & 4 & 3 & 3 & 1 \\
\hline & & Dijil & 4 & 3 & 2 & 1 \\
\hline & Gentle & Debre Mewi & 4 & 3 & 2 & 1 \\
\hline & & Dijil & 3 & 4 & 2 & 1 \\
\hline
\end{tabular}

Table 7 | Farmers' ranking of SWC measures on the evaluation criteria for different slopes (3, Best; 1, Worst): Anjeni watershed.

\begin{tabular}{|c|c|c|c|c|}
\hline Criteria & Slope & Fanya juu & Stone bund & No measure \\
\hline \multirow[t]{3}{*}{ Minimize soil losses (erosion control) } & Steep & 2 & 3 & 1 \\
\hline & Moderate & 3 & 2 & 1 \\
\hline & Gentle & 3 & 2 & 1 \\
\hline \multirow[t]{3}{*}{ Enhance soil fertility } & Steep & 2 & 3 & 1 \\
\hline & Moderate & 3 & 2 & 1 \\
\hline & Gentle & 3 & 2 & 1 \\
\hline \multirow[t]{3}{*}{ Maximize water retention } & Steep & 3 & 2 & 1 \\
\hline & Moderate & 3 & 2 & 1 \\
\hline & Gentle & 3 & 2 & 1 \\
\hline \multirow[t]{3}{*}{ Maximize crop yields } & Steep & 2 & 3 & 1 \\
\hline & Moderate & 3 & 2 & 1 \\
\hline & Gentle & 3 & 2 & 1 \\
\hline \multirow[t]{3}{*}{ Maximize fodder (grass) production } & Steep & 3 & 1 & 1 \\
\hline & Moderate & 3 & 1 & 1 \\
\hline & Gentle & 3 & 1 & 1 \\
\hline \multirow[t]{3}{*}{ Minimize labor requirement for establishment } & Steep & 2 & 1 & 3 \\
\hline & Moderate & 2 & 1 & 3 \\
\hline & Gentle & 2 & 1 & 3 \\
\hline \multirow[t]{3}{*}{ Minimize maintenance costs } & Steep & 1 & 2 & 3 \\
\hline & Moderate & 1 & 2 & 3 \\
\hline & Gentle & 1 & 2 & 3 \\
\hline \multirow[t]{3}{*}{ Maximize ox-plowing convenience } & Steep & 2 & 1 & 3 \\
\hline & Moderate & 2 & 1 & 3 \\
\hline & Gentle & 2 & 1 & 3 \\
\hline \multirow[t]{3}{*}{ Minimize risks of pest harboring effect } & Steep & 2 & 1 & 3 \\
\hline & Moderate & 2 & 1 & 3 \\
\hline & Gentle & 2 & 1 & 3 \\
\hline \multirow[t]{3}{*}{ Minimize dispute with adjacent farmers } & Steep & 2 & 3 & 1 \\
\hline & Moderate & 3 & 2 & 1 \\
\hline & Gentle & 3 & 2 & 1 \\
\hline
\end{tabular}


Table 8 | Experts' ranking of SWC measures on the evaluation criteria for different slopes (4, Best; 1, Worst).

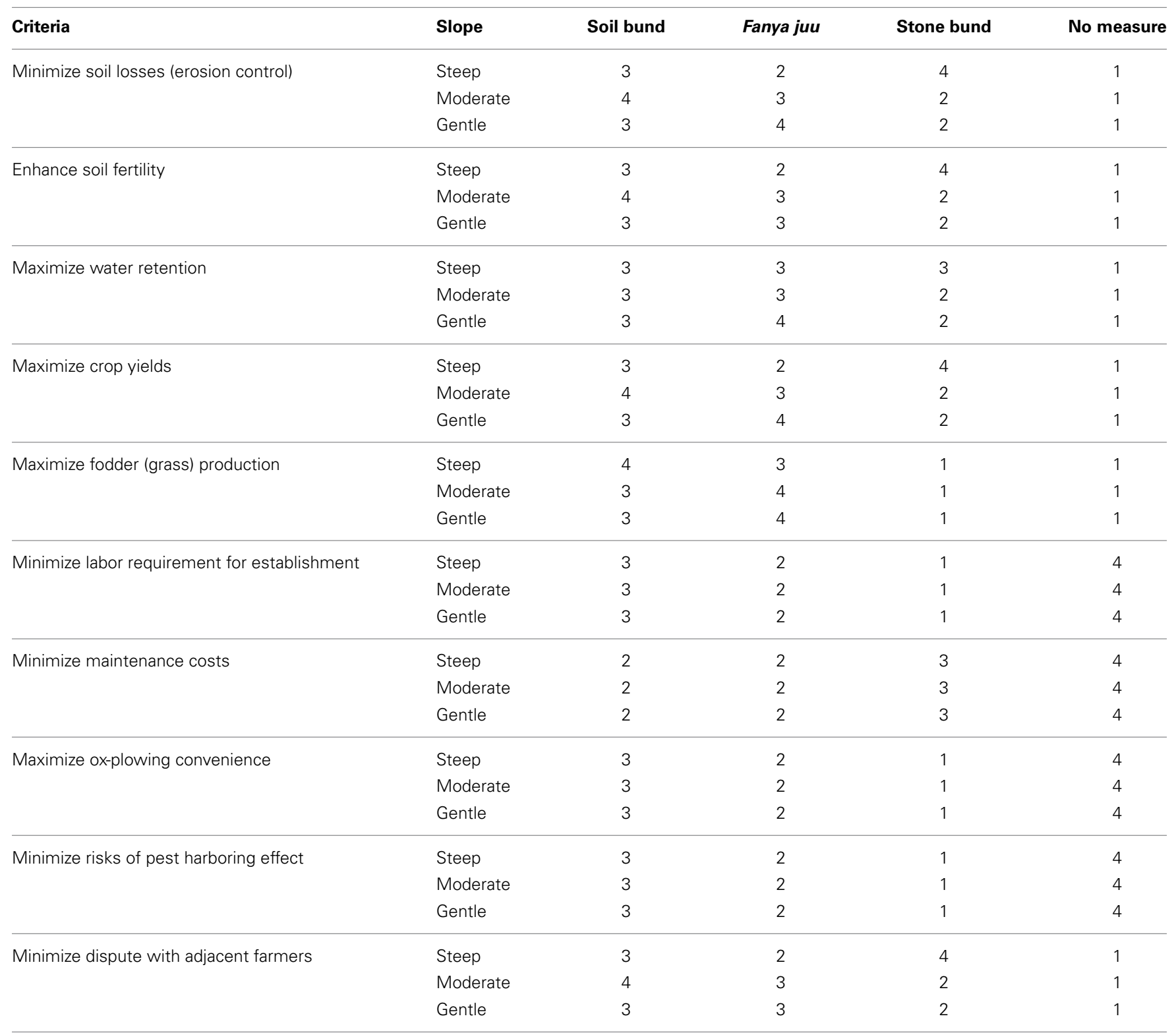

and experts ranked Fanya juu as the least effective alternative next to "No measures" in steeply sloping areas, as high runoff would easily rupture these structure. Thus, the main objective of farmers in steep areas is to control erosion and consequently, farmers know that stone bunds are the most effective measure.

\section{Moderate slope category}

For moderate sloping areas, soil bunds are the best alternative for farmers (Debre Mewi) and experts; however in the Dijil and Anjeni areas, Fanya juu is preferred. As water erosion is not as severe on moderate slopes, soil embankments are deemed a suitable measure. Farmer weightings also indicate that increasing yields represents the main objective on moderate slopes (Table 4).

\section{Gentle slope category}

Fanya juu bunds were the most preferred alternative on plots with gentle slopes in Dijil and Anjeni but not in the Debre Mewi watershed. Farmers invest in SWC on gentle sloped areas to increase production and productivity to help achieve higher profitability for their practice; similar to the moderate slope category. Farmers of Debre Mewi preferred soil bunds for moderate and gentle slopes categories due to their long time experience with soil bunds (Table 11).

\section{DISCUSSION}

There are differences between the weight sets of farmers and those of experts. Farmers in the three watersheds give social and other criteria on all three slope categories a weighting of about $17 \%$, while this is only $11 \%$ among experts. The latter underestimate 


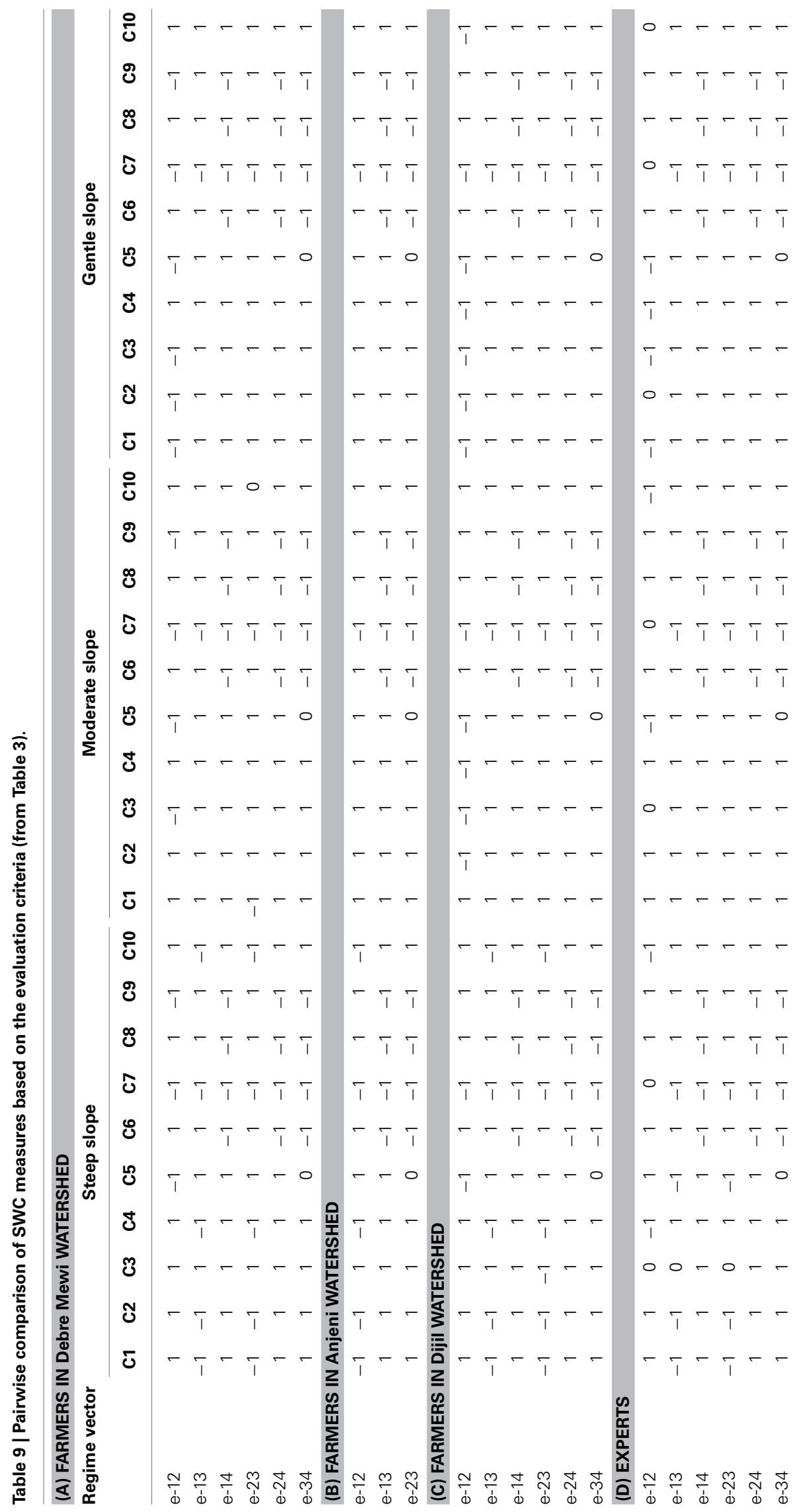


Table 10 | The weighted scores of the pairwise comparisons and overall rank (Rk) of the alternatives for each slope category, by watershed and for farmers and experts.

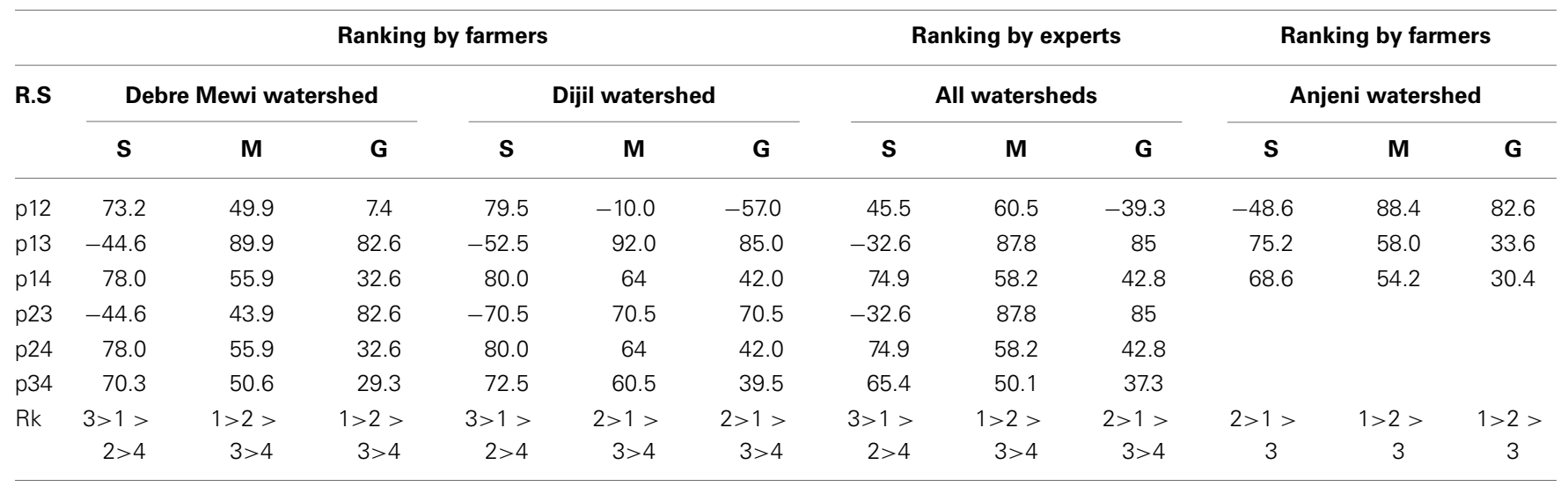

Table 11 | MCA ranking of the SWC measures by farmers and experts.

\begin{tabular}{|c|c|c|}
\hline Watershed & Slope & Ranking \\
\hline \multicolumn{3}{|c|}{ RANKING BY FARMERS } \\
\hline \multirow[t]{3}{*}{ Debre Mewi } & Steep & $\begin{array}{l}\text { Stone bunds }>\text { soil bunds }>\text { Fanya juu }> \\
\text { no measure }\end{array}$ \\
\hline & Moderate & $\begin{array}{l}\text { Soil bunds }>\text { Fanya juu }>\text { stone bunds }> \\
\text { no measure }\end{array}$ \\
\hline & Gentle & $\begin{array}{l}\text { Soil bunds }>\text { Fanya juu }>\text { stone bunds }> \\
\text { no measure }\end{array}$ \\
\hline \multirow[t]{3}{*}{ Anjeni } & Steep & Stone bunds $>$ Fanya juu $>$ no measure \\
\hline & Moderate & Fanya juu $>$ stone bunds $>$ no measure \\
\hline & Gentle & Fanya juu $>$ stone bunds $>$ no measure \\
\hline \multirow[t]{3}{*}{ Dijil } & Steep & $\begin{array}{l}\text { Stone bunds }>\text { soil bunds }>\text { Fanya juu }> \\
\text { no measure }\end{array}$ \\
\hline & Moderate & $\begin{array}{l}\text { Fanya juu }>\text { soil bund }>\text { stone bund }>\text { no } \\
\text { measure }\end{array}$ \\
\hline & Gentle & $\begin{array}{l}\text { Fanya juu }>\text { soil bund }>\text { stone bund }>\text { no } \\
\text { measure }\end{array}$ \\
\hline \multicolumn{3}{|c|}{ RANKING BY EXPERTS } \\
\hline \multirow[t]{3}{*}{ All watersheds } & Steep & $\begin{array}{l}\text { Stone bund }>\text { soil bund }>\text { Fanya juu }>\text { no } \\
\text { measure }\end{array}$ \\
\hline & Moderate & $\begin{array}{l}\text { Soil bund }>\text { Fanya juu }>\text { stone bund }>\text { no } \\
\text { measure }\end{array}$ \\
\hline & Gentle & $\begin{array}{l}\text { Fanya juu }>\text { soil bund }>\text { stone bund }>\text { no } \\
\text { measure }\end{array}$ \\
\hline
\end{tabular}

the issues of ease of plowing, pest harboring effects, and disputes. The experts on the other hand attach higher weighting to the three ecological criteria and to earnings from grass production; aspects which they focus on in their extension messages. This is in line with the findings of Tenge (2005).

The results of the analysis also illustrate that farmers often stick to practices that they are more familiar with. In Debre Mewi, farmers on moderate and gentle slopes prefer soil bunds above Fanya juu, since they have become accustomed to soil bunds and not (yet) to Fanya juu. In Anjeni and (to a lesser extent) Digil, farmers already have lengthy (over 30 years) experience with Fanya juu and therefore prefer this SWC measure on moderate and gentle slopes. It is interesting to note that among the experts, there was one favorite measure for each slope category: stone bunds for steep slopes, soil bunds for moderate slopes and Fanya juu for gentle slopes. But experts should still look at each particular situation and should not come up with rigid guidelines.

Farmers take into account ecological, economic, social, and other impacts of the SWC when they select SWC practices to meet multiple objectives. Thus, adoption of SWC practices by farmers is not solely based on economic or monetary values as usually demonstrated through CBA (Tenge, 2005; Amsalu, 2006). This suggests that SWC practices that fulfill both economic and other considerations of farmers can contribute to the continued adoption of SWC.

Furthermore, this study revealed that SWC practices have ecological, economic and social benefits. However, SWC practices are mostly evaluated by CBA. These SWC practices are sometimes not profitable from a private-economic point of view (Kassie et al., 2011; Adimassu et al., 2012). This is because the ecological and social benefits of SWC practices they are not quantified in monetary values. Thus, holistic evaluation methods (e.g., MCA) are important to evaluate the overall benefits of SWC practices. Moreover, MCA accommodates diverse views, interests, preferences, and expertise of the stakeholders (Balana et al., 2010). However, MCA with ordinal data does not incorporate the time dimension of costs and benefits, which is pertinent for SWC measures that need a long time for benefits to be realized. The time dimension of SWC can be incorporated within MCA through the use of an efficiency criteria of CBA. The following describes such an example.

Undertaking a CBA for a standard slope of $10 \%$, with an assumed 20 years lifetime of the measures and a $12.5 \%$ discount rate, it was found that in Debre Mewi soil bunds (with grassed risers) and stone bunds had a Net Present Value (NPV) of 1819 and $1265 \mathrm{EtB} \mathrm{ha}^{-1}$ over 20 years, respectively $(1 \mathrm{EtB} \approx 0.056$ \$S in 2013). Since Fanya Juu was only recently introduced in the Debre Mewi watershed, it was not taken into account. In the Anjeni watershed, soil bunds (rare in this watershed), Fanya juu (both with grassed risers) and stone bunds, scored a NPV of 1902, 2718, and $2217 \mathrm{EtB} \mathrm{ha}^{-1}$, respectively (Teshome et al., 2013). Since 
these detailed calculations were only made for the most common slopes of $10 \%$, these results can only be used for the moderate slope category, for two watersheds and three SWC alternatives. This information on financial efficiency (expressed by NPV) was subsequently used for the economic impact within the Regime Analysis (replacing the four separate cost and benefit criteria). The information on the other (ecological and social/other) evaluation criteria remained the same. The results of this analysis show the same ranking as in the previous analysis for the moderate slopes in the two watersheds: soil bunds better than stone bunds in Debre Mewi watershed and Fanya juu better than stone bunds in Anjeni watershed. The measures were in both cases better than no measure.

\section{CONCLUSIONS}

A number of SWC practices in the north-western highlands of Ethiopia using MCA were evaluated to assess their ecological, economic and social impacts. The study revealed that MCA is an effective evaluation tool that can take into account nonmonetary and less quantifiable effects of SWC measures, which is not possible with a CBA.

The results of the analysis indicate that farmers in the northwestern highlands of Ethiopia have a range of criteria to evaluate the performance of SWC measures. The relative importance of each criterion in the selection of SWC alternatives depends to a large extent on slope categories. Farmers in the study areas gave the highest score for criteria related to ecological impacts in steeply sloping areas, and prefer alternatives with stronger positive economic impacts in moderate and gentle sloping areas. Furthermore, stone bunds were deemed the best SWC alternative on steep slopes in all watersheds. Fanya juu bunds are the most preferred alternative on plots with gentle slopes in the Dijil and Anjeni watersheds. This indicates that SWC alternatives must be promoted based on farmers' preferences and specific agroecological conditions such as slope. Thus, in order to facilitate the adoption of SWC practices, a blanket recommendation approach must be avoided. The extension service should deliver a range of SWC options for the needy farmers from which to select an appropriate SWC measure that is governed by their preferences and plot situation. In addition, the Research-Extension-Farmers linkage must be strengthened in order to identify and disseminate appropriate technologies based on farmer needs. To conclude, policy makers and development practitioners should pay more attention to farmer SWC preferences and particular circumstances (e.g., slope) in designing SWC strategies and programmes.

\section{REFERENCES}

Adgo, E., Teshome, A., and Mati, B. (2013). Impacts of long-term soil and water conservation on agricultural productivity: the case of Anjenie watershed, Ethiopia. Agric. Water Manag. 117, 55-61. doi: 10.1016/j.agwat.2012.10.026

Adimassu, Z., Mekonnen, K., Yirga, C., and Kessler, A. (2012). Effect of soil bunds on runoff, soil and nutrient losses, and crop yield in the central highlands of Ethiopia. Land Degrad. Dev. doi: 10.1002/ldr.2182

Amsalu, A. (2006). Caring for the Land: Best Practices in Soil and Water Conservation in Beresa Watershed, Highlands of Ethiopia. Ph.D. thesis, Wageningen University, Wageningen.

Ananda, J., and Herath, G. (2009). A critical review of multi-criteria decision making methods with special reference to forest management and planning. Ecol. Econ. 68, 2535-2548. doi: 10.1016/j.ecolecon.2009.05.010
Balana, B.B., Mathijs, E., and Muys, B. (2010). Assessing the sustainability of forest management: an application of multi-criteria decision analysis to community forests in northern Ethiopia. J. Environ. Manage. 91, 1294-1304. doi: 10.1016/j.jenvman.2010.02.005

Bizoza, A.R., and de Graaff, J. (2012). Financial cost-benefit analysis of bench terraces in Rwanda. Land Degrad. Dev. 23, 103-115. doi: 10.1002/ldr.1051

Boggia, A., and Cortina, C. (2010). Measuring sustainable development using a multi-criteria model: a case study. J. Environ. Manage. 91, 2301-2306. doi: 10.1016/j.jenvman.2010.06.009

CIFOR (Centre for International Forestry Research). (1999). Guidelines for Applying Multi criteria Analysis to the Assessment of Criteria and Indicators. Jakarta: CIFOR.

de Graaff, J. (1996). The Price of Soil Erosion: an Economic Evaluation of Soil Conservation and Watershed Development. Ph.D. thesis, Wageningen Agricultural University, Wageningen.

Fleskens, L., Nainggolan, D., and Stringer, L. C. (2014). An exploration of scenarios to support sustainable land management using integrated environmental socioeconomic models. Environ. Manag. 54, 1005-1021.

Haile, M., Herweg, K., and Stillhardt, B. (2006). Sustainable Land Management A New Approach to Soil and Water Conservation in Ethiopia. Land Resources Management \& Environmental Protection Departement Mekelle University, Ethiopia, Centre for Development and Environment (CDE), National Centre of Competence in Research (NCCR) North-South, Mekelle.

Haileslassie, A., Priess, J., Veldkamp, E., Teketay, D., and Lesschen, J.P. (2005). Assessment of soil nutrient depletion and its spatial variability on smallholders' mixed farming systems in Ethiopia using partial versus full nutrient balances. Agric. Ecosyst. Environ. 108, 1-16. doi: 10.1016/j.agee.2004.12.010

Hajkowicz, S. (2007). A comparison of multiple criteria analysis and unaided approaches to environmental decision making. Environ. Sci. Policy 10, 177-184. doi: 10.1016/j.envsci.2006.09.003

Hajkowicz, S., and Higgins, A. (2008). A comparison of multiple criteria analysis techniques for water resource management. Eur. J. Oper. Res. 184, 2550-2265. doi: 10.1016/j.ejor.2006.10.045

Hajkowicz, S., McDonald, G. T., and Smith, P.H. (2000). An evaluation of multiple objective decision support weighting techniques in natural resource management. J. Environ. Plann. Manag. 43, 505-518 doi: 10.1080/7136 76575

Hengsdijk, H., Meijerink, G. W., and Mosugu, M. E. (2005). Modeling the effect of three soil and water conservation practices in Tigray, Ethiopia. Agric. Ecosyst. Environ. 105, 29-40. doi: 10.1016/j.agee.2004.06.002

Hinloopen, E., and Nijkamp, P. (1990). Qualitative multiple criteria choice analysis: the dominant regime method. Qual. Quant. 24, 37-56.

Kassie, M., Kohlin, G., Bluffstone, R., and Holden, S. (2011). Are soil conservation technologies "win-win"? A case study of Anjeni in the North-Western Ethiopian Highlands. Nat. Resour. Forum 35, 89-99 doi: 10.1111/j.14778947.2011.01379.x

Kassie, M., Zikhali, P., Manjur, K., and Edwards, S. (2009). Adoption of sustainable agriculture practices: Evidence from a semi-arid region of Ethiopia. Nat. Resour. Forum 33, 189-198. doi: 10.1111/j.1477-8947.2009.01224.x

Liu, B.M., Collick, A.S., Zeleke, G., Adgo, E., Easton, Z.M., and Steenhuis, T.S. (2008). Rainfall-discharge relationships for a monsoonal climate in the Ethiopian highlands. Hydrol. Process. 22, 1059-1067. doi: 10.1002/hyp.7022

Mendoza, G.A., and Martins, H. (2006). Multi-criteria decision analysis in natural resource management: a critical review of methods and new modelling paradigms. Forest Ecol. Manag. 230, 1-22. doi: 10.1016/j.foreco.2006. 03.023

Munda, G., Nijkamp, P., and Rietveld, P. (1994). Qualitative multicriteria evaluation for environmental management. Ecol. Econ. 10, 97-112. doi: 10.1016/09218009(94)90002-7

Pender, J., and Gebremedhin, B. (2007). Determinants of agricultural and land management practices and impacts on crop production and household income in the highlands of Tigray, Ethiopia. J. Afr. Econ. 17, 395-450. doi: 10.1093/jae/ejm028

Prato, T. (1999). Multiple attribute decision analysis for ecosystem management. Ecol. Econ. 30, 207-222 doi: 10.1016/S0921-8009(99)00002-6

Romero, C., and Rehman, T. (2003). Multiple Criteria Analyis for Agricultural Decision, 2nd Edn. Amsterdam: Elseveir Science B. V.

SCRP (Soil Conservation Research Project). (1991). Soil Conservation Progress Report 8, Vol. 9. Bern: University of Bern. 
Seo, F., and Sakawa, M. (1988). Multiple Criteria Decision Analysis in Regional Planning. Concepts, Methods and Application. Tokyo: D. Reidel Publishing Company.

Tefera, B., and Sterk, G. (2010). Land management, erosion problems and soil and water conservation in Fincha'a watershed, Western Ethiopia. Land Use Policy 27, 1027-1037. doi: 10.1016/j.landusepol.2010.01.005

Tenge, A.J. (2005). Participatory Appraisal for Farm-Level Soil and Water Conservation Planning in West Usambara Highlands, Tanzania. Ph.D. thesis, Wageningen University, Wageningen.

Tesfaye, A., Negatu, W., Brouwer, R., and van der Zaag, P. (2013). Understanding soil conservation decision of farmers in the Gedeb watershed, Ethiopia. Land Degrad. Dev. 25, 71-79. doi: 10.1002/ldr.2187

Tesfaye, H. (2011). Assessment of Sustainable Watershed Management Approach Case Study Lenche Dima, Tsegur Eyesus and Dijil Watershed. Master of Professional Studies thesis, Cornell University, Bahir Dar.

Teshome, A., de Graaff, J., and Kassie, M. (Forthcoming). Household level determinants of soil and water conservation adoption phases in the north-western Ethiopian highlands. Environ. Manag.

Teshome, A., de Graaff, J., Ritsema, C., and Kassie, M. (2014). Farmers' perceptions about influence of land quality, land fragmentation and tenure systems on sustainable land management investments in the North Western Ethiopian Highlands. Land Degrad. Dev. doi: 10.1002/ ldr. 2298

Teshome, A., Rolker, D., and de Graaff, J. (2013). Financial viability of soil and water conservation technologies in north-western Ethiopian highlands. Appl. Geogr. 37, 139-149. doi: 10.1016/j.apgeog.2012.11.007

Vega, D. C., and Alpízar, F. (2011). Choice experiments in environmental impact assessment: the case of the Toro 3 hydroelectric project and the Recreo Verde tourist center in Costa Rica. Impact Assess. Proj. Appraisal 29, 252-262. doi: 10.3152/146155111X12959673795804

Voogd, J.H. (1982). Multi-Criteria Evaluation for Urban and Regional Planning. London: Pion.

Yitbarek, T.W., Belliethathan, S., and Stringer, L.C. (2012). The onsite cost of gully erosion and cost-benefit of gully rehabilitation: a case study in Ethiopia. Land Degrad. Dev. 23, 157-166. doi: 10.1002/ldr.1065

Zegeye, A.D. (2009). Assessment of Upland Erosion Processes and Farmer's Perception of Land Conservation in Debre-Mewi Watershed, Near Lake Tana, Ethiopia. Master of Professional Studies thesis, Cornell University, Bahir Dar.

Conflict of Interest Statement: The authors declare that the research was conducted in the absence of any commercial or financial relationships that could be construed as a potential conflict of interest.

Received: 05 August 2014; accepted: 29 November 2014; published online: 23 December 2014.

Citation: Teshome A, de Graaff J and Stroosnijder L (2014) Evaluation of soil and water conservation practices in the north-western Ethiopian highlands using multicriteria analysis. Front. Environ. Sci. 2:60. doi: 10.3389/fenvs.2014.00060

This article was submitted to Agroecology and Land Use Systems, a section of the journal Frontiers in Environmental Science.

Copyright (C) 2014 Teshome, de Graaff and Stroosnijder. This is an open-access article distributed under the terms of the Creative Commons Attribution License (CC BY). The use, distribution or reproduction in other forums is permitted, provided the original author(s) or licensor are credited and that the original publication in this journal is cited, in accordance with accepted academic practice. No use, distribution or reproduction is permitted which does not comply with these terms. 